\title{
First Faunistic Record of Alphitophagus bifasciatus (Say, 1823) (Coleoptera: Tenebrionidae) from East Anatolia (Turkey)
}

\author{
İnanç ÖZGEN
}

Firat University, Engineering Faculty, Bioengineering Department, Elazı̆̆, Turkey ORCID ID: İnanç ÖZGEN: https:/ / orcid.org/0000-0003-1742-9324

\begin{abstract}
Received: 23.11.2020
Accepted: 05.12.2020

Published online: 12.12 .2020

Issue published: 31.12 .2020

Abstract: With this study, brief information about the new distribution area and economic importance of the Alphitophagus bifasciatus (Say, 1823) (Coleoptera: Tenebrionidae) is given. It has been found in cereals, oilseeds, and in their products such as copra, cocoa, nuts, feed, dried fruit, herbs, and spices in previous years. It is possible in the following years that it will be characterized as potentially harmful by causing economic damage in the paddy fields in the Eastern and Southeastern Anatolia Regions of Turkey. Determining the specimen in this region is important in terms of faunistic and economic entomology in order to investigate the agricultural control management in the countries where it is pest related to the species and to reveal the plant protection strategy.
\end{abstract}

Keywords: Alphitophagus bifasciatus, distribution, economic importance, potential pest.

\section{Alphitophagus bifasciatus (Say, 1823) (Coleoptera: Tenebrionidae)'un Doğu Anadolu Bölgesi'ndeki İlk Faunistik Kayıtı}

Öz: Bu çalışmayla; Alphitophagus bifasciatus (Say, 1823) (Coleoptera: Tenebrionidae)'un dağıllış alanı ve ekonomik önemi ile ilgili kısa bilgiler sunulmaktadır. Tür; daha önceki yıllarda tahıllar, yağlı tohumlar ve bunların ürünleri olan kopra, kakao, kuruyemiş, yem, kuru meyve, otlar ve baharatlar gibi ürünlerde bulunmuştur. Türün ileriki yıllarda, Doğu ve Güneydoğu Anadolu Bölgelerinde pirinç ekiliş alanlarında ekonomik önemde zarar oluşturarak potansiyel zararlı konumuna geçmesi muhtemeldir. Türün bu bölgede belirlenmesi; tür ile ilgili zararlı olduğu ülkelerde tarımsal mücadele yönetiminin araştırılması ve bitki koruma stratejisinin ortaya çıkarılması açısından faunistik ve ekonomik entomoloji açısından önemlidir.

Anahtar kelimeler: Alphitophagus bifasciatus, dağılış, ekonomik önemi, potansiyel zararlı.

The «two-banded fungus beetle» Alphitophagus bifasciatus was recorded for the first time in East Anatolia (Turkey). Although it is of Mediterranean origin, it immediately spread across the region. It is harmful for arid stored cereals (Hagstrum \& Subramanyam, 2009). Starchcontaining foodstuffs are preferred by pests. It can be fed on rotten fruits. It was distributed commonly moldy and damp areas in Turkey. It has been identified as harmful in the paddy plants in Balıkesir province (Atabay, Aydin, \& Özder, 2013). The fact that the species damage especially paddy field areas will make it a potentially harmful in the coming years as it causes economic damage in the Eastern and Southeastern Anatolia regions. Determining the species is important in terms of faunistic and economic entomology in order to investigate the agricultural control management in the countries where it is pest related to the species and to reveal the plant protection strategy. It should not be overlooked if especially Karacadağ rice from local varieties and commercial varieties to be grown. The samples were collected by shifter and they were preserved in $70 \%$ ethanol. In additionally; A. bifasciatus adults were collected from the rotten leaf deposits of the oak plant.

Material examined: Elazığ, Günbağı village, 21.07.2019, Quercus cerris. 12 exc. leg. Özgen (Fig. 1).

Note: It was found on decayed organic material.

They were found in cereals, oilseeds, and in their products such as kopra, cocoa, nuts, feed, dried fruits, herbs, and spices.
Although this species is not the main pest, it is thought that there may be problems in the following years especially in the paddy fields if the humidity increases and the grain storage conditions deteriorate. It is thought to be effective on the pest population fluctuations and wintering behavior of rotten leaves and plant debris to near the gardens and fields. That's why this situation should be considered in the struggle against the pest.

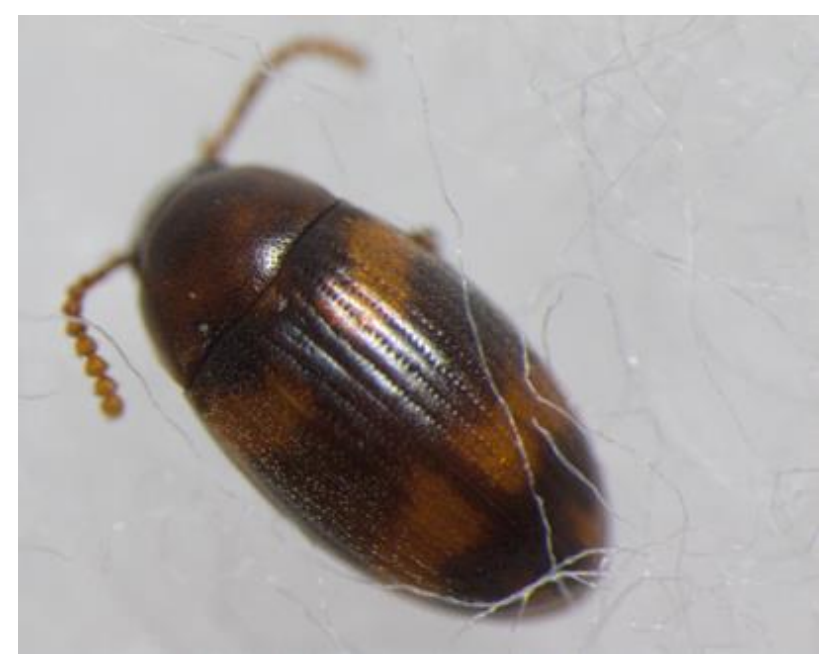

Figure 1. The Habitus of Alphitophagus bifasciatus (Say, 1823). 


\section{References}

Atabay, S., Aydın, V., \& Özder, N. (2013). Insect pests of stored paddy and rice in Balıkesir (Gönen) and Edirne (Uzunköprü). Plant Protection Bulletin, 53(3), 141-157.

Buchelos, TH., \& Athanassiou, C.G. (1993). First Record of Alphidohagus bifasciatus (Say) (Coleoptera: Tenebrionidae) from Greece; Its Occurrence in Cereal Product Stores. Entomologia Hellenica, 11, 41-42.

Hagstrum, D.W., \& Subramanyam B. (2009). Stored-Product Insect Resource. 508 pp. 